\title{
Absolute Dating of John the Baptist, the Crucifixion of Jesus Christ, and Paul the Apostle
}

\author{
Rainer Walter Kühne \\ Bürgerstr. 4, 38118 Braunschweig, Germany \\ e-mail: kuehne70@gmx.de
}

I suggest the following scenario. In the fifteenth year of the reign of Tiberius (14-37), that is late in 28 or early in 29, John began to preach a baptism. Jesus healed and preached and was crucified on the Preparation Day, Friday 3 April 33 during a lunar eclipse. Thereafter the apostles began to preach and raising the number of believers from 120 to 5000 . This caused a persecution where Saul converted to Paul late in 33. Afterwards Paul spent three years in Damascus, where Aretas IV was king. Thereafter Paul did his first travel which lasted for fourteen years, that is $36-50$. This was followed by the council of the apostles late in 50 . Thereafter Paul did his second travel which lasted for at least a year and six months. Then he did his third travel which lasted for at least two years and six months, that is 52-54. Afterwards he was imprisoned for two years by Antonius Felix until Porcius Festus became procurator of Judaea in 56.

There is general agreement that Jesus Christ was a historical person. Experts differ in dating his crucifixion (between 27 and 34) and the council of the apostles (between 48 and 51). Here I would like to investigate these two open questions.

In his loudaike archaiologia historian Josephus Flavius mentioned John the Baptist (Antiquitates Judaicae 18.5.2). He mentioned also that James, the brother of Jesus called Christus, was executed in 62 (Antiquitates Judaicae 20.200). In the bible, James is mentioned as a brother of Jesus (Mark 6.3; Matthew 13.55; Galatians 1.19). Cornelius Tacitus mentioned that Christus was executed by the procurator Pontius Pilate during the reign of Tiberius (Annales 15.44). Moreover Christus was mentioned by Caius Suetonius Tranquillus (De vita Caesarum - vita Claudii 25.4) and Caius Plinius Caecilius Secundus (Epistola ad Traianum 10.96.7). So both Jesus Christ and John the Baptist were historical persons.

In the fifteenth year of the reign of Tiberius Caesar the word of God came to John the son of Zacharias in the wilderness and he went into all the region around the Jordan, preaching a baptism (Luke 3.1-3). Tiberius Claudius Nero, who was renamed as Tiberius lulius Caesar Augustus, became emperor on 19 August 14 (Cornelius Tacitus, Annales 1.6.1) and passed away on 16 March 37 (Cornelius Tacitus, Annales 6.50.4; Caius Suetonius Tranquillus, De vita Caesarum 73.1), so the year is 28 or 29.

All the canonical gospels agree that Jesus was baptized by John (Mark 1.9; Matthew 3.13; Luke 3.21; John 1.28-31). When Jesus heard that John had been put in prison, he departed to Galilee. And leaving Nazareth, he came and dwelt in Capernaum. From that time Jesus began to preach (Matthew 4.12-17; also Mark 1.14). Jesus began his ministry at about thirty years of age (Luke 3.23 ).

A short time later Jesus came to Jerusalem for Passover (John 2.23). Jesus visited Jerusalem also for a feast of the Jews (John 5.1). At a later time Passover was near (John 6.4). Jesus was also in the temple (John 7.14) during the Feast of Tabernacles (John 7.2) and in winter during the Feast of Dedication (John 10.22-23). Jesus planned to come to 
Jerusalem for Passover (John 12.1), what was shortly before his end (John 13.1). However, this chronology is not historical but a compilation.

During his ministry Jesus preached and/or healed in Capernaum (Mark 1.21; 2.1; 9.33; Matthew 4.13; 8.5; 11.23; 17.24; Luke 4.31; 7.1; 10.15; John 2.12), the country of the Gadarenes (Mark 5.1; 8.28; Luke 8.26), Nazareth (Mark 6.1; Matthew 13.54; Luke 4.16), Chorazin (Matthew 11.21; Luke 10.13), Bethsaida (Mark 6.45; Matthew 11.21; Luke 10.13), the land of Gennesaret (Mark 6.53; Matthew 14.34), the region of Tyre and Sidon (Mark 7.31; Matthew 15.21), Caesarea Philippi (Mark 8.27; Matthew 16.13), Jericho (Mark 10.46; Matthew 20.29; Luke 18.35), Bethany (Mark 11.12; 14.3; Matthew 21.17; 26.6; Luke 19.29; John 11.1; 12.1), Nain (Luke 7.11), Cana of Galilee (John 2.1; 4.16), and Sychar of Samaria (John 4.5).

Jesus was questioned by the high priest Caiaphas (Matthew 26.57; John 18.13-28) and the governor Pontius Pilate (Mark 15.1-15; Matthew 27.2-13; Luke 23.1-24; John 18.2919.13). In fact Joseph Caiaphas was high priest between 18 (Josephus Flavius,

Antiquitates Judaicae 18.2.2) and 36 and Pontius Pilate was praefectus ludaeae from 26 (Josephus Flavius, Antiquitates Judaicae 18.3.1) until 36 (Josephus Flavius, Antiquitates Judaicae 18.4.2). So the crucifixion of Jesus must have occurred between 26 and 36 .

The four canonical gospels describe the time of the crucifixion as follows. Now when the sixth hour had come, there was darkness over the whole land until the ninth hour. And at the ninth hour Jesus cried out and breathed his last. Now evening has come, it was Preparation Day, that is the day before the Sabbath (Mark 15.33-42). From the sixth hour until the ninth hour there was darkness over all the land. About the ninth hour Jesus cried out with a loud voice and yielded up his spirit. Now after the Sabbath as the first day of the week began to dawn women came to see the tomb (Matthew 27.45-28.1). Then the sun was darkened. Jesus cried out with a loud voice and breathed his last. That day was the Preparation, and the Sabbath drew near (Luke 23.44-54). Jesus gave up his spirit.

Therefore, because it was Preparation Day, that the bodies should not remain on the cross on the Sabbath (John 19.30-31).

Preparation Day means that it was the first full moon in spring. Matthew (28.1) and Luke (23.54) mean that it was Friday before Sabbath. The Jewish day began on sunset, so the sixth hour was around midnight and Jesus passed away between 2 and 3 a.m.

During the reign of Pontius Pilate (26-36) the first full moon in spring (14 or 15 Nisan) fell four times on a Thursday-Friday, that is 10-11 April 27, 6-7 April 30, 2-3 April 33, and 22-23 April 34. A solar eclipse (Luke 23.45) can occur neither at midnight nor at full moon, however, a lunar eclipse can. The only lunar eclipse that occurred during the reign of Pontius Pilate on a Friday during the first full moon in spring was on 3 April 33 (Clive Ruggles, "The Moon and the crucifixion," Nature, Vol. 345 (1990) pp. 669-670). So Jesus Christ passed away on Friday, 3 April 33 between 2 and 3 a.m.

Jesus commanded the apostles not to depart from Jerusalem (Acts 1.4). After the death of Jesus, Peter stood up in the midst of the disciples, altogether the number of names was about a hundred and twenty (Acts 1.15). As the apostles spoke to the people, the priests, the captain of the temple, and the Sadducees came upon them and put them in custody until the next day (Acts 4.1-3). However, many of those who heard the word believed and the number of the men came to be about five thousand (Acts 4.4). The men who had been put in prison were again standing in the temple and teaching the people. So they were set before the council and asked by the high priest (Acts 5.25-27). Stephen was stoned (Acts 
7.59) and Saul was consenting to his death (Acts 8.1). At a later time Saul was under the impression that Jesus had appeared to him (Acts 9.3-9), so he came to Jerusalem and tried to join the disciples (Acts 9.26).

After the revelation Saul, who renamed as Paul, spent three years in Arabia and Damascus, before he went to Jerusalem (Galatians 1.15-18). In Damascus the governor, under Aretas the king, was guarding the city but Paul escaped from his hands (2 Corinthians 11.32-33). King Aretas IV passed away in 39.

Hereafter Paul did his first travel. He started in Jerusalem (Acts 12.25), visited Antioch (Acts 13.1), Seleucia and Cyprus (Acts 13.4), Salamis on Cyprus (Acts 13.5), Paphos on Cyprus (Acts 13.6), Perga in Pamphylia (Acts 13.13), Antioch in Pisidia (Acts 13.14), Iconium (Acts 14.1), Lystra and Derbe of Lycaonia (Acts 14.6), Lystra, Iconium and Antioch (Acts 14.21), Pamphylia, Perga and Attalia (Acts 14.24-25), Antioch (Acts 14.26), Phoenicia and Samaria (Acts 15.3), and returned to Jerusalem (Acts 15.4). This travel which started and finished in Jerusalem lasted for fourteen years (Galatians 2.1).

This travel was followed by the council of the apostles (Acts 15.4-9). Thereafter Paul started his second travel where he visited Antioch (Acts 15.35), Syria and Cilicia (Acts 15.41), Derbe and Lystra (Acts 16.1), Phrygia and Galatia (Acts 16.6), Troas (Acts 16.8), Samothrace and Neapolis (Acts 16.11), Philippi in Macedonia for some days (Acts 16.12), Amphipolis, Apollonia and Thessalonica for three weeks (Acts 17.1-2), Athens (Acts 17.15), Corinth (Acts 18.1) for a year and six months (Acts 18.11) when Gallio was proconsul of Achaia (Acts 18.12) - indeed Lucius lunius Gallio Annaeanus was proconsul Achaiae 51-52 (Gallio inscription, Sylloge inscriptionum graecarum, III, 801D; Delphi inscription, Inscriptiones Graecae, VII, 1676) - visited Cenchrea and Syria (Acts 18.18), Ephesus (Acts 18.19), Caesarea and returned to Antioch (Acts 18.22).

Thereafter Paul started his third travel in Antioch and visited Galatia and Phrygia (Acts 18.23), Ephesus (Acts 19.1) for three months in the synagogue (Acts 19.8) and for two years at the school of Tyrannus (Acts 19.9-10), Macedonia (Acts 20.1), Greece for three months (Acts 20.2-3), Macedonia (Acts 20.3), Assos (Acts 20.14), Mitylene, Chios, Samos, Trogyllium and Miletus (Acts 20.15), Ephesus (Acts 20.17), Cos, Rhodes and Patara (Acts 21.1), Syria and Tyre (Acts 21.3), Caesarea (Acts 21.8) and finished in Jerusalem (Acts 21.17). After two years Porcius Festus succeeded (Acts 24.27) governor Felix (Acts 24.1$3)$.

So Paul's travel lasted for fourteen years. His second travel lasted for at least a year and six months. His third travel lasted for at least two years and sixth months. Afterwards Paul spent two years in Jerusalem before Porcius Festus became governor. Indeed Porcius Festus succeeded Antonius Felix as procurator of Judaea in 56 (Rudolf Helm, Die griechischen christlichen Schriftsteller der ersten Jahrhunderte, Vol. 24, Eusebius Werke VII, Die Chronik des Hieronymus (1913), p. 182).

To conclude, the chronology of events can be reconstructed as follows. In 56 Porcius Festus became procurator of Judaea. Two years earlier, in 54, Paul finished his third travel and was imprisoned by Antonius Felix. Paul's third travel lasted for at least two years and six months, that is 52-54. Paul's second travel lasted for at least a year and six months including a time when Lucius lunius Gallio Annaeanus was proconsul Achaiae in 51-52, so the second travel was 50-52. The council of the apostles occurred in 50. Paul's first travel lasted for fourteen years, so 36-50. Paul stayed in Damascus for three years, that is 33-36. Saul converted to Paul late in 33. Jesus was crucified on the Preparation Day, Friday 3 
April 33, when there was a lunar eclipse which lasted for three hours, and passed away between 2 and 3 a.m. John started baptism late in 28 or early in 29 , the fifteenth year of the reign of Tiberius. 